\title{
PERLIDUNGAN HUKUM TERHADAP PELAKSANAAN KESELAMATAN DAN KESEHATAN KERJA (K3) PADA PERUSAHAAN*
}

\author{
Erni Darmayanti \\ Fakultas Hukum, Universitas Potensi Utama Medan \\ Jl. Menteng VII, Gg. Garuda No. 14 Ke. Medan Tenggara, Kec. Medan Denai, Medan. \\ e-mail: esindank@yahoo.com
}

\begin{abstract}
Legal protection concerning Occupational Safety and Health at company, given in effort of prevention (preventive) to avoid accident and cause work-related diseases. The Importance of Occupational Safety and Health is closely related to employee performance and ultimately affects the company's performance. In this case, this study discusses: First, general understanding of Occupational Safety and Health (K3), Second, How is the protection of law regarding Occupational Safety and Health (K3) according to the laws and regulations in Indonesia. This research is a normative juridical research with secondary data collection method that is research of library (library research) in the form of primary law material, secondary law material and tertiary legal material. The results of this study explain that the safety of work on the company is included in the technical protection, where the protection of the worker in question is for workers to be safe from the harm that can be caused by work tools or materials and work health which is also intended to protect or keep workers from the events harm health and decency in doing his job. Implementation Legal protection of Occupational Safety and Health in legislation in accordance with Law No. 1 of 1970 on Occupational Safety and Law No. 13 of 2003.
\end{abstract}

Keywords: Legal Protection, Occupational Safety and Health, Company

\begin{abstract}
Abstraksi
Perlindungan hukum mengenai Keselamatan dan Kesehatan Kerja pada perusahaan, diberikan dalam upaya pencegahan (preventif) agar tidak terjadi kecelakaan dan menimbulkan penyakit akibat kerja. Pentingnya Keselamatan dan Kesehatan Kerja sangat terkait dengan kinerja karyawan dan pada akhirnya mempengaruhi kinerja perusahaan. Dalam hal ini, penelitian ini membahas tentang: Pertama, Pengertian secara umum mengenai Keselamatan dan kesehatan kerja (K3), Kedua, Bagaimana perlindungan hukum mengenai Keselamatan dan Kesehatan Kerja (K3) menurut peraturan perundang-undangan di Indonesia. Penelitian ini merupakan penelitian yuridis normatif dengan metode pengumpulan data sekunder yaitu penelitian kepustakaan (library research) berupa bahan hukum primer, bahan hukum sekunder dan bahan hukum tertier. Hasil penelitian ini menjelaskan bahwa keselamatan kerja pada perusahaan termasuk dalam perlindungan teknis, dimana perlindungan terhadap pekerja yang dimaksud adalah agar pekerja selamat dari bahaya yang dapat ditimbulkan oleh alat kerja atau bahan yang dikerjakan dan kesehatan kerja yang juga dimaksudkan untuk melindungi atau menjaga pekerja dari kejadian yang merugikan kesehatan dan kesusilaan dalam melakukan pekerjaannya. Pelaksanaan Perlindungan hukum terhadap Keselamatan dan Kesehatan Kerja dalam perundang-undangan sesuai dengan Undang-Undang Nomor 1 Tahun 1970 Tentang Keselamatan Kerja dan Undang-Undang Nomor 13 Tahun 2003 Tentang Ketenagakerjaan.
\end{abstract}

Kata Kunci: Perlindungan Hukum, Keselamatan dan Kesehatan Kerja Perusahaan

\footnotetext{
* Naskah diterima: 14 Februari 2018, direvisi: 01 Maret 2018, disetujui untuk terbit: 29 Maret 2018
} 


\section{PENDAHULUAN}

Dalam Pasal 27 ayat (2) UndangUndang Dasar Negara Kesatuan Republik Indonesia Tahun 1945 ada peraturan yang menyatakan bahwa setiap warga negara memiliki hak pekerjaan dan penghidupan yang layak bagi kemanusiaan. Pasal ini memberi makna bahwa negara menjamin hak setiap orang untuk mendapatkan perlindungan dan kenyamanan dalam melaksanakan pekerjaannya.

Perlindungan yang dimaksudkan adalah adanya jaminan tentang perlakuan yang sama tanpa adanya diskriminasi atas dasar apapun dalam mewujudkan kesejahteraan bagi pekerja dan keluarganya, namun tetap memperhatikan perkembangan zaman serta kemajuan dunia usaha dan kepentingan pengusaha.

Dalam pelaksanaan pembangunan nasional, pekerja mempunyai peranan dan kedudukan penting sebagai pelaku dalam mencapai tujuan pembangunan. Pekerja adalah merupakan aset perusahaan yang sangat penting dan harus dibekali dengan perlindungan Keselamatan dan Kesehatan Kerja (K3) oleh perusahaan, karena mengingat tingginya ancaman-ancaman terhadap keselamatan dan kesehatan pekerja selama melakukan pekerjaannya di perusahaan tempatnya bekerja, sehingga berpotensi menimbulkan gangguan hubungan kerja antara pekerja dengan perusahaan. ${ }^{1}$

${ }^{1}$ Gerry Silaban dan Salomo Perangin-angin, 2008, Hak Dan Atau Kewajiban Tenaga Kerja Dan Pengusahal Pengurus Yang Ditetapkan Dalam Peraturan Perundangan Keselamatan Dan Kesahatan Kerja, USU Press, Medan, Hlm. 1
Semakin berkembangnya dunia usaha di Indonesia, selain untuk menciptakan lapangan pekerjaan, perusahaan juga bertujuan untuk memperoleh keuntungan. Dimana dalam hal ini, perusahaan menganggap hal yang terpenting adalah mengambil keuntungan yang sebesarbesarnya. Sehingga perusahaan mendorong para pekerja untuk bekerja lebih giat sesuai dengan kebutuhan pasar. Yang mana tidak jarang menyebabkan pekerja menjadi cedera. Cedera yang dimaksud dalam hal ini sangat beragam, dari cedera pada otot sampai kepada cedera yang menyebabkan adanya korban jiwa.

Dalam Undang-Undang Nomor 1 Tahun 1970 Tentang Keselamatan Kerja (UUKK), telah dijelaskan yaitu dengan pesatnya kemajuan industrialisasi, mekanisme dan modernisasi, maka berlangsung pulalah peningkatan terhadap intensitas kerja operasional para pekerja, mesin-mesin, alat-alat, pesawat-pesawat baru dan sebagainya pada perusahaan. Sehingga kurang memperhatikan secara rinci, misalnya bahan-bahan teknis dan bahan-bahan yang mengandung racun, serta cara-cara kerja yang buruk, kekurangan keterampilan dan latihan kerja, tidak adanya pengetahuan tentang sumber bahaya yang baru. Hal ini lah yang senantiasa sering menjadi sumbersumber bahaya dan penyakit yang ditimbulkan akibat kerja pada perusahaan. Maka dapatlah dipahami, bahwa perlu adanya pengetahuan Keselamatan dan Kesehatan Kerja (K3) di perusahaan yang maju dan tepat. Karena masalah kesehatan 
Erni Darmayanti: Perlidungan Hukum Terhadap Pelaksanaan Keselamatan...

yang merupakan salah satu unsur yang harus diperhitungkan. Sesuai dengan Undang-Undang Nomor 23 Tahun 1992 Tentang Kesehatan, dimana produktivitas kerja harus senantiasa diwujudkan secara optimal agar setiap pekerja dapat bekerja dengan sehat tanpa membahayakan dan mengakibatkan kerugian terhadap dirinya dan orang lain serta perusahaan. ${ }^{2}$

Menurut Kepala BPJS Ketenagakerjaan Sumbagut, Umardin Lubis, mengatakan data kecelakaan kerja BPJS Ketenagakerjaan hingga 30 Oktober 2017, terjadi kecelakaan kerja sebanyak 88.000 kasus atau rata-rata 303 kasus per bulan. ${ }^{3}$

Keselamatan dan Kesehatan Kerja (K3) sudah menjadi standar penilaian pada perusahaan. Karena keselamatan dan kesehatan kerja sangan berkaitan erat dengan kelangsungan berjalannya operasional perusahaan, sehingga kalau perusahaan gagal menerapkannya, maka perusahaan akan dianggap tidak layak dan tidak peduli terhadap keselamatan dan kesehatan pekerja.

Berdasarkan uraian dari tersebut diatas, selanjutnya dapat dirumuskan pokok-pokok permasalahannya yaitu menjelaskan pengertian secara umum mengenai Keselamatan dan Kesehatan Kerja (K3) dan bagaimana perlindungan hukum mengenai Keselamatan dan

Kerja",

http://data.tp.ac.id/dokumen/kumpulan+3\#downlo ad,

${ }^{3}$ https://www.wartaekonomi.co.id/read16163 8/bpjs-tk-sumbagut-catat-kecelakaan-kerja-303kasus-perbulan.html
Kesehatan Kerja (K3) menurut peraturan perundang-undangan di Indonesia.

\section{METODOLOGI PENELITIAN}

Adapun metode penelitian yang dipergunakan dalam penelitian ini adalah penelitian yuridis normatif yakni penelitian yang difokuskan untuk mengkaji norma-norma dalam hukum positif, yang dilakukan dengan cara meneliti bahan-bahan kepustakaan yang relevan dengan permasalahan yang diteliti. Bahan hukum yang digunakan adalah:

a. Bahan hukum primer adalah bahan yang telah ada dan berhubungan dengan penelitian yang terdiri dari seperti Undang-Undang Nomor 1 Tahun 1970 Tentang Keselamatan Kerja, Undang-Undang Nomor 13 Tahun $2003 \quad$ Tentang Ketenagakerjaan, Peraturan Menteri Tenaga Kerja Republik Indonesia Nomor Per-01/Men/1998 Tentang Penyelenggaraan Pemeliharaan Kesehatan Bagi Tenaga Kerja Dengan Manfaat Lebih Baik Dari Paket Jaminan Pemeliharaan Kesehatan Dasar Jaminan Sosial Tenaga Kerja, Peraturan Menteri Tenaga Kerja Nomor 05 Tahun 1996 Tentang Sistem Manajemen Keselamatan dan Kesehatan Kerja (SMK3) dan Bahan hukum sekunder adalah berupa publikasi tentang hukum yang meliputi buku-buku teks, penelitian para ahli, hasil karya ilmiah dan buku-buku ilmiah yang berhubungan dengan penelitian ini.

b. Bahan hukum tertier adalah bahanbahan hukum yang menunjang guna memberi petunjuk dan penjelasan, 
seperti kamus umum, kamus hukum yang melengkapi bahan hukum primer dan sekunder.

\section{HASIL DAN PEMBAHASAN}

\section{Pengertian Keselamatan dan Kesehatan Kerja (K3)}

a. Keselamatan Kerja

Keselamatan kerja (Occupational Safety) yang sehari-hari disebut dengan safety, secara filosofi diartikan sebagai suatu pemikiran dan upaya untuk menjamin keutuhan dan kesempurnaan baik jasmaniah maupun rohaniah pekerja pada khususnya dan manusia pada umumnya. $^{4}$ Keselamatan kerja erat kaitannya dengan mesin-mesin, alat kerja, bahan dan proses pengolahannya, landasan tempat kerja dan lingkungan serta cara-cara melakukan pekerjaan di perusahaan yang kemungkinan besar dapat menimbulkan kecelakaan kerja. ${ }^{5}$ Kecelakaan kerja yang dimaksud adalah suatu kejadian atau peristiwa yang tidak diinginkan yang merugikan manusia atau dalam hal ini pekerja dan dapat merusak harta benda.

Keselamatan kerja adalah bebas dari kecelakaan (Accident) pada waktu bekerja ditempat kerja (Occupational Safety

4 Direktorat Sarana dan Prasarana Institut Teknologi Bandung, "Kesehatan Dan Keselamatan Kerja”, http:// kesehatandankeselamatankerja.blogspot.com/2009 /01/pengertian-keselamatan-dan-kesehatankerja.html

${ }^{5}$ Suma'mur, 1987, Keselamatan Kerja dan Pencegahan Kecelakaan, CV. Haji Masagung, Jakarta, Hlm. 1 means free from accident at the place of work). Tujuan keselamatan kerja adalah: ${ }^{6}$

1. Melindungi tenaga kerja atas hak keselamatannya dalam melakukan pekerjaan untuk kesejahteraan hidup dan meningkatkan produksi dan produktivitas nasional.

2. Menjamin keselamatan setiap orang lain yang berada ditempat kerja.

3. Sumber produksi dipelihara dan dipergunakan secara aman dan efisien.

Peraturan yang mengatur tentang keselamatan kerja ini adalah UndangUndang Nomor 1 Tahun 1970 Tentang Keselamatan Kerja, menjelaskan bahwa keselamatan kerja adalah mencegah dan mengurangi kecelakaan kerja, memadamkan bahaya kebakaran, dan mengurangi bahaya-bahaya peledakan. Namun sebagian besar peraturan pelaksanaan undang-undang ini belum ada sehingga beberapa peraturan warisan Hindia Belanda masih dijadikan pedoman dalam pelaksanaan keselamatan kerja di perusahaan. Misalnya: Veiligheidsreglement, S. 1910 No. 406 yang telah beberapa kali diubah, terakhir dengan S. 1931 No. 168 yang kemudian setelah Indonesia merdeka diberlakukan dengan Peraturan Pemerintah No. 208 Tahun 1947. Kemudian berdasarkan Undang-Undang No. 25 Tahun 1997 tentang perlindungan atas keselamatan karyawan, dimana dalam hal ini pasal 108 telah menjamin keselamatan dan

6 J.H. Ritonga, 1990, Pengetahuan Dasar Keselamatan Kerja Dan Pencegahan Kecelakaan, CV. Garut Narisi Corp, Jakarta, Hlm. 5. 
Erni Darmayanti: Perlidungan Hukum Terhadap Pelaksanaan Keselamatan...

kesehatan kerja, moral dan kesusilaan dan pelaksanaan kerja yang sesuai dengan harkat dan martabat sebagai manusia serta nilai-nilai agama.

\section{b. Kesehatan Kerja}

Kesehatan merupakan nikmat dan anugerah dari Tuhan Yang Maha Esa yang tidak ternilai harganya. Oleh karena itu, setiap manusia ingin mendapatkan kesehatan dan menjaganya agar terhindar dari segala penyakit yang dapat mengganggu segala aktivitas manusia. Kesehatan merupakan suatu kondisi fisik, mental dan sosial seseorang yang bebas dari penyakit atau gangguan kesehatan dalam lingkungan dan pekerjaan.

Kesehatan kerja termasuk kedalam perlindungan sosial, karena berkaitan dengan sosial kemasyarakatan. Dimana pengusaha memperlakukan pekerjanya sesuai dengan norma-norma yang berlaku dan memandang pekerja sebagai mahluk Tuhan yang mempunyai hak asasi. ${ }^{7}$ Pekerja yang menderita gangguan kesehatan atau penyakit akibat kerja cenderung lebih mudah mengalami kecelakaan kerja. Jadi peraturan mengenai kesehatan kerja bermaksud untuk melindungi atau menjaga pekerja dari kejadian atau keadaan hubungan kerja yang merugikan kesehatan dan kesusilaan pekerja dalam melakukan pekerjaannya. Pekerjaan yang dimaksud adalah pekerjaan yang dijalankan oleh pekerja untuk pengusaha dalam hubungan kerja dengan menerima upah. Dalam suatu hubungan kerja, pekerja yang tidak

\footnotetext{
${ }^{7}$ Ibid, Hlm. 87
}

melakukan hubungan kerja dengan pengusaha tidak mendapatkan perlindungan sosial sebagaimana ditentukan dalam Undang-Undang Nomor 13 Tahun 2003 Tentang Ketenagakerjaan.

Kesehatan Kerja merupakan suatu hal penting dan perlu diperhatikan oleh pihak pengusaha. Karena dengan adanya kesehatan yang baik maka akan menguntungkan pekerja dan pengusaha, karena pekerja akan lebih jarang absen dan bekerja dalam lingkungan yang menyenangkan, sehingga secara keseluruhan pekerja akan mampu bekerja lebih lama. Pada dasarnya kesehatan kerja adalah merupakan alat untuk mencapai tingkat kesehatan pekerja menjadi lebih baik, sehingga dengan sendirinya menjadi kesejahteraan pekerja dan meningkatkan produktivitas manusia dalam bekerja.

Kesehatan kerja adalah spesialisasi ilmu kesehatan/kedokteran beserta prakteknya yang bertujuan agar pekerja memperoleh derajat kesehatan setinggitingginya baik fisik, mental maupun sosial dengan usaha preventif terhadap penyakit/gangguan kesehatan yang diakibatkan oleh faktor pekerjaan dan lingkungan kerja serta terhadap penyakit umum. Ditempat kerja, kesehatan pekerja sangat dipengaruhi oleh: ${ }^{8}$

1. Beban kerja berupa beban fisik, mental dan sosial sehingga upaya penempatan pekerja yang sesuai dengan kemampuannya perlu diperhatikan.

${ }^{8}$ Direktorat Sarana dan Prasarana Institut Teknologi Bandung, Op.Cit, Hlm. 1 
2. Kapasitas kerja yang banyak tergantung pada pendidikan, keterampilan, kesegaran jasmani, ukuran tubuh, keadaan gizi dan sebagainya.

3. Lingkungan kerja sebagai beban tambahan, baik berupa faktor fisik, kimia, biologi, ergonomik maupun aspek psikososial.

Keselamatan dan kesehatan kerja adalah suatu program untuk melindungi yang dibuat bagi pekerja maupun pengusaha sebagai upaya pencegahan (Preventif) bagi timbulnya kecelakaan kerja dan penyakit akibat kerja dalam lingkungan kerja, yaitu dengan cara mengenali hal-hal yang berpotensi menimbulkan kecelakaan kerja dan penyakit akibat kerja. Tujuan utama keselamatan dan kesehatan kerja adalah mencegah, mengurangi bahkan menghilangkan resiko kecelakaan kerja (Zero Accident). Yang dapat mengakibatkan atau mencegah terjadinya cacat/kematian pada pekerja, mencegah kerusakan tempat dan peralatan kerja dan mencegah pencemaran lingkungan dan masyarakat di sekitar tempat kerja.

Maka Keselamatan dan Kesehatan Kerja (K3) harus diterapkan dan dilaksanakan di setiap perusahaan, dimana menanggung jawab mengenai Keselamatan dan Kesehatan Kerja (K3) ditempat kerja adalah pengusaha atau pimpinan atau pengurus tempat kerja, dan pengurusannya dilaksanakan secara bersama oleh pimpinan atau pengurus perusahaan dan seluruh pekerja. Karena bagi pekerja, adanya jaminan perlindungan keselamatan kerja akan menimbulkan suasana kerja yang tenteram sehingga pekerja dapat memusatkan perhatiannya pada pekerjaannya semaksimal mungkin tanpa khawatir sewaktu-waktu akan tertimpa kecelakaan kerja. ${ }^{9}$

\section{Perlindungan Hukum terhadap Pelaksanaan Keselamatan dan Kesehatan Kerja (K3) menurut Peraturan Perundang-undangan di Indonesia}

Sejalan dengan sejarah purbakala, maka keselamatan dan kecelakaan juga sama tuanya dengan bangsa Indonesia. Namun pada saat itu keselamatan, baik umum maupun khusus dalam kaitan pekerjaan, lebih bersifat perorangan. Masalah keselamatan dalam perusahaan mulai terasa, terutama untuk melindungi modal yang ditanam. Namun keadaan tidak banyak berubah sampai pertengahan abad ke-19, saat itulah telah dipakai 120 (seratus dua puluh) ketel uap yang merupakan suatu teknologi baru pada zaman tersebut. Undang-undang uap diadakan Tahun 1853, penggunaan ketel uap ini sangat cepat berkembang. Seperti pada Tahun 1898 dipakai 2.277 ketel uap untuk listrik sebagai sumber penerangan dan kadang-kadang sumber tenaga perlu mendapat perhatian tentang pengawasan keselamatannya. Pada Tahun 1980 dikeluarkan ketetapan tentang pemasangan dan pemakaian jaringan saluran listrik di Indonesia. Masalah

9 Zaeni Asyhadie, 2008, Hukum Kerja (Hukum Ketenagakerjaan Bidang Hubungan Kerja), PT. Raja Grafindo Persada, Jakarta, Hlm. 104 
Erni Darmayanti: Perlidungan Hukum Terhadap Pelaksanaan Keselamatan...

keselamatan angkutan, terutama tentara Belanda menjadi lebih penting. Pada Tahun 1907, diadakan pengaturan tentang pengangkutan obat, senjata, petasan, peluru dan bahan-bahan yang dapat meledak bagi kepentingan Angkatan Bersenjata dengan angkutan kereta api. Kemudian lebih banyak lagi indistriindustri yang relatif besar didirikan, sehingga perlu dikeluarkan "Veiligheidsreglement" pada Tahun 1905 beserta peraturan-peraturan khusus sebagai pelengkap pelaksanaannya dan revisi pada Tahun 1910. Pada Tahun 1930 pemerintah Belanda merevisi undangundang uap, masa-masa diantara Tahun 1931-1936 adalah saat depresi ekonomi, namun begitu jumlah perusahaan tidak berkurang, melainkan hanya mengurangi kegiatan-kegiatannya. Pada Tahun 1940, keluar pengaturan tentang biaya pemeriksaan keselamatan kerja di perusahaan.

Selama Perang Dunia ke-II, tidak ada hal-hal penting yang dapat dicatat mengingat zaman itu adalah keadaan perang. Sejak Indonesia merdeka, keselamatan kerja berkembang sesuai dengan dinamika Bangsa Indonesia. Beberapa tahun setelah Proklamasi Kemerdekaan, undang-undang kerja dan undang-undang kecelakaan (Kompensasi) diundangkan. Kemudian dimasukkan jawatan-jawatan pelaksanaan undangundang pada tubuh Departemen Perburuhan, antara lain jawatan pengawasan keselamatan kerja. Pada Tahun 1957, didirikan Lembaga Kesehatan dan Keselamatan Kerja. Pada
Tahun 1970, Undang-Undang Nomor 1 Tantang Keselamatan Kerja diundangkan. Undang-undang ini mengganti "Veiligheidsreglement" Tahun 1910. Pada Tahun 1973 berdiri Ikatan Higene Perusahaan, Kesehatan dan Keselamatan Kerja (K3), yang menghimpun juga profesi dalam keselamatan kerja.

Beberapa peraturan mengenai Keselamatan dan Kesehatan Kerja (K3), yaitu:

\section{a. Undang-Undang}

1. Undang-Undang Nomor 1 tahun 1970 tentang Keselamatan Kerja

Undang-undang ini diundangkan untuk menggantikan Veiligheidsregement Tahun 1910 (stb. No. 406). UU No. 1 Tahun 1970 Tentang Keselamatan Kerja ini tidak secara tegas dicabut, dengan demikian hal-hal yang belum diatur dalam peraturan pelaksana lainnya maka ketentuan-ketentuan yang terdapat dalam UU No. 1 Tahun 1970 dianggap masih berlaku dan mencakup di semua tempat kerja, baik di darat, di dalam tanah, di permukaan air, di dalam air, maupun di udara di wilayah negara Republik Indonesia. $^{10}$

Undang-Undang Nomor 1 Tahun 1970 Tentang Keselamatan Kerja mengalami pembaharuan dan perluasan, yaitu: (1) perluasan ruang lingkup, (2) perubahan pengawasan yang bersifat represif menjadi preventif, (3) perumusan teknis yang lebih tegas, (4) penyesuaian

10 Agusmidah, 2010, Dinamika Hukum Ketenagakerjaan Indonesia, USU Press, Medan, HIm. 73 
tata usaha/administrasi yang diperlukan bagi pelaksana pengawas. (5) tambahan pengaturan pembinaan keselamatan kerja bagi manajemen dan tenaga kerja, (6) tambahan pengaturan pemungutan retribusi tahunan.

$$
\text { Syarat keselamatan kerja }
$$
diberlakukan di tempat kerja antara lain peralatan yang dianggap berbahaya, pekerjaan konstruksi dan perawatan bangunan, usaha pertanaman kehutanan dan perikanan, usaha pertambangan, usaha pengangkutan barang dan manusia, usaha penyelam, pekerjaan dengan tekanan udara atau suhu tinggi/rendah, pekerjaan dalam tangki atau lubang, serta di tempat kerjanya yang terdapat atau menyebarkan suhu, kelembaban, debu, kotoran, api, asap, uap, gas, hembusan angin, cuaca, sinar, radiasi, suara dan getaran. Dalam Pasal 3 Undang-Undang Nomor 1 Tahun 1970 Tentang Keselamatan Kerja ada ditetapkan syaratsyarat keselamatan kerja yaitu: ${ }^{11}$
a. Mencegah, mengurangi dan memadamkan kebakaran.
b. Mencegah dan mengurangi bahaya peledakan.
c. Memberi kesempatan atau jalan menyelamatkan diri pada waktu kebakaran atau kejadian lain yang berbahaya.

d. Memberi pertolongan pada kecelakaan.

e. Memberi alat perlindungan diri kepada para pekerja.

f. Mencegah dan mengendalikan timbul atau menyebar luasnya suhu, kelembaban, debu, kotoran, asap, uap, gas, hembusan angin, cuaca sinar atau radiasi, suara dan getaran.

g. Mencegah dan mengendalikan timbulnya penyakit akibat kerja baik fisik maupun phychis, infeksi dan penularan.

h. Memperoleh penerangan yang cukup dan sesuai.

i. Menyelenggarakan suhu dan lembap udara yang baik.

j. Menyelenggarakan penyegaran udara yang cukup.

k. Memelihara kebersihan, kesehatan dan ketertiban.

1. Memperoleh keserasian antara tenaga kerja, alat kerja, lingkungan, cara dan proses kerjanya.

m. Mengamankan dan memperlancar pengangkutan orang, binatang, tanaman atau barang.

n. Mengamankan dan memelihara segala jenis bangunan.

o. Mengamankan dan memperlancar pekerjaan bongkar muat, perlakuan dan penyimpanan barang.

p. Mencegah terkena aliran listrik yang berbahaya.

q. Menyesuaikan dan menyempurnakan pengamanan pada pekerjaan yang bahaya kecelakaannya menjadi bertambah tinggi.

2. Undang-undang Republik Indonesia Nomor 13 Tahun 2003 Tentang Ketenagakerjaan

Dalam undang-undang ini perlindungan hak normatif bagi tenaga kerja yaitu diatur dalam $\mathrm{Bab} \mathrm{X}$ tentang

\footnotetext{
${ }^{11}$ Ibid, Hlm. 74
} 
Erni Darmayanti: Perlidungan Hukum Terhadap Pelaksanaan Keselamatan...

perlindungan, pengupahan dan kesejahteraan.

1. Perlindungan

a. Perlindungan Pekerja

1) Perlindungan terhadap Penyandang Cacat

Pekerja cacat oleh undang-undang diberi perlindungan dan jaminan untuk melakukan hubungan kerja antara pekerja dengan pengusaha. Pasal 67 UndangUndang Ketenagakerjaan dengan tegas menyebutkan terhadap pengusaha yang mempekerjakan tenaga kerja penyandang cacat wajib memberikan perlindungan sesuai dengan jenis dan derajat kecacatannya. Perlindungan sebagai mana dimaksud misalnya penyediaan aksesibilitas, pemberian alat kerja, dan alat pelindung diri yang disesuaikan dengan jenis dan derajat kecacatannya tersebut. $^{12}$ Hal ini merupakan bentuk usaha pemerintah dalam menegakkan jaminan kepastian bagi setiap tenaga kerja untuk memperoleh pekerjaan dan penghidupan yang layak sesuai dengan kemanusiaan, sebagaimana yang diamanatkan dalam UUD NKRI Tahun 1945 dalam Pasal 27 ayat (2) dan 28 D ayat (2). ${ }^{13}$ Kategori penyandang cacat terdiri dari (a) Penyandang cacat fisik, adalah kecacatan yang mengakibatkan gangguan pada fungsi tubuh, antara lain gerak tubuh, penglihatan, pendengaran, dan kemampuan bicara. (b) Penyandang cacat mental., adalah kelainan mental dan/atau tingkah laku, baik cacat bawaan

\footnotetext{
${ }^{12}$ Agusmidah, Op. Cit., Hlm. 56

${ }^{13}$ Ibid, Hlm. 58
}

maupun akibat dari penyakit. (c) Penyandang cacat fisik dan mental, adalah keadaan seseorang yang menyandang dua jenis kecacatan sekaligus.

2) Perlindungan terhadap Pekerja Anak

Pasal 1 angka 26 Undang-Undang Ketenagakerjaan menjelaskan bahwa anak adalah setiap orang yang berumur dibawah 18 (delapan belas) tahun. ${ }^{14}$ Maka batasannya adalah (a) Pekerja anak adalah anak-anak yang bekerja baik sebagai tenaga upahan maupun pekerja keluarga. (b) Pekerja anak adalah anak yang bekerja di sektor formal maupun informal dengan berbagai status hubungan kerja.

Pengusaha dilarang mempekerjakan anak, kecuali bagi anak yang berumur antara 13 (tiga belas) tahun sampai dengan 15 (lima belas) tahun untuk (a) Melakukan pekerjaan ringan sepanjang tidak mengganggu perkembangan dan kesehatan fisik, mental, dan sosial. (b) Untuk mengembangkan bakat dan minat dengan syarat dibawah pengawasan langsung orang tua/wali, waktu kerja paling lama 3 (tiga) jam sehari dan kondisi dan lingkungan kerja tidak mengganggu perkembangan fisik, mental, sosial, dan waktu sekolah., (c) Khusus bagi anak yang berusia minimum 14 tahun, untuk pekerjaan yang merupakan bagian dari kurikulum pendidikan atau pelatihan yang disahkan oleh pejabat yang berwenang, maka anak yang dipekerjakan bersama-sama dengan pekerja dewasa, memiliki tempat kerja anak yang harus

${ }^{14}$ Ibid, Hlm. 62 
dipisahkan dari tempat kerja pekerja dewasa. $^{15}$

3) Perlindungan terhadap Pekerja Perempuan

Perlindungan terhadap pekerja perempuan secara keseluruhan terkait dengan perlindungan ekonomis, perlindungan sosial dan perlindungan teknis. Perlindungan ekonomis diantaranya menyangkut upah dan tunjangan lainnya tidak boleh dibedakan dengan pekerja laki-laki untuk jenis pekerjaan dan jabatan yang sama, selain itu terhadap perempuan yang menjalankan masa istirahat dikarenakan haid, melahirkan atau keguguran kandungan tetap mendapat upah penuh. ${ }^{16}$

b. Perlindungan Jam Kerja dan Waktu Istirahat

Waktu kerja dan waktu istirahat merupakan jaminan perlindungan pekerja di tempat kerja untuk menghindari adanya perlakuan tidak manusiawi terhadap pekerja mengenai jam kerja yang berlebihan sehingga dapat mengganggu kesehatan dan keselamatan. (a) Waktu kerja yang diatur dalam Undang-Undang Nomor 13 Tahun 2003 Tentang Ketenagakerjaan, kecuali bagi sektor usaha atau pekerjaan tertentu (misalnya pengeboran minyak lepas pantai, sopir angkutan jarak jauh, penerbangan jarak jauh, pekerjaan di kapal (laut) atau penebangan hutan. Pasal 77 UndangUndang Ketenagakerjaan menyebutkan

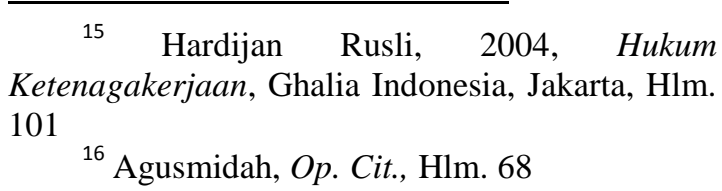

bahwa setiap pengusaha wajib melaksanakan ketentuan waktu kerja apabila dilakukan penyimpangan atas jam kerja tersebut maka pengusaha harus mengajukan izin dari lembaga yang berwenang dan harus melakukan pembayaran/kompensasi sesuai peraturan tentang kerja lembur dan upah kerja lembur. (b) Waktu istirahat bagi pekerja adalah Istirahat antara jam kerja sekurang-kurangnya setengah jam setelah bekerja 4 (empat) jam terus-menerus dan waktu istirahat tersebut tidak termasuk jam kerja dan Istirahat mingguan 1 (satu) hari untuk 6 (enam) hari kerja dalam 1 (satu) minggu atau 2 (dua) hari untuk 5 (lima) hari kerja dalam 1 (satu) minggu. Selain istirahat, pekerja/buruh berhak atas cuti untuk tidak melaksanakan pekerjaannya yaitu cuti tahunan yang sekurang-kurangnya 12 (dua belas) hari kerja setelah pekerja/buruh yang bersangkutan bekerja selama 12 (dua belas) bulan secara terus-menerus dan istirahat panjang yang sekurangkurangnya 2 (dua) bulan dan dilaksanakan pada tahun ketujuh dan kedelapan, masing-masing 1 (bulan) bagi pekerja/buruh yang telah bekerja selama 6 (enam) tahun secara terus-menerus pada perusahaan yang sama. ${ }^{17}$

$$
\begin{array}{ll}
\text { c. Perlindungan } & \text { Mengenai } \\
\text { Keselamatan dan } & \text { Kesehatan } \\
\text { Kerja (K3) } &
\end{array}
$$

Merupakan jenis perlindungan pencegahan (Preventif) yakni pengawasan yang dilakukan sebelum terjadinya penyelewengan-penyelewengan,

\footnotetext{
${ }^{17}$ Ibid, Hlm. 72
} 
Erni Darmayanti: Perlidungan Hukum Terhadap Pelaksanaan Keselamatan...

kesalahan-kesalahan, dan sebelum suatu pekerjaan dilaksanakan dengan memberi pedoman-pedoman pelaksanaan, yang diterapkan untuk mencegah timbulnya kecelakaan dan penyakit akibat kerja. ${ }^{18}$ Dalam hal ini, pengusaha diwajibkan memberikan hak pekerja yakni melindungi Keselamatan dan Kesehatan Kerja (K3) tenaga kerja sesuai dengan Pasal 86 Undang-Undang Nomor 13 Tahun 2003 Tentang Ketenagakerjaan, yakni keselamatan dan kesehatan kerja, moral dan kesusilaan dan perlakuan yang sesuai dengan harkat dan martabat manusia serta nilai-nilai agama.

\section{Pengupahan}

Setiap pekerja berhak memperoleh penghasilan yang layak bagi kemanusiaan (Pasal 88 ayat (1) Undang-Undang Nomor 13 Tahun 2003 Tentang Ketenagakerjaan), dalam hal ini ukuran layak adalah relatif. Bentuk perlindungan upah antara lain perlindungan upah saat hari libur resmi (Pasal 92 UndangUndang Nomor 13 Tahun 2003 Tentang Ketenagakerjaan) dan perlindungan upah yang lainnya adalah denda (Pasal 95, Pasal 96 Undang-Undang Nomor 13 Tahun 2003 Tentang Ketenagakerjaan). Pelanggaran yang dilakukan oleh pekerja karena kesengajaan atau kelalaiannya dapat dikenakan denda. Pengusaha yang karena kesengajaan atau kelalaiannya mengakibatkan keterlambatan pembayaran upah, dikenakan denda

\footnotetext{
${ }^{18}$ Sendjun H. Manulang, 2001, Pokok-Pokok Hukum Ketenagakerjaan Ketenagakerjaan Indonesia, PT. Asdi Mahasatya, Jakarta, Hlm. 83
}

sesuai dengan persentase tertentu dari upah pekerja. 19

3. Kesejahteraan

Perwujudan Keselamatan dan Kesehatan Kerja (K3) yang ditujukan sebagai perlindungan khusus bagi tenaga kerja, yaitu dibuatlah Jamsostek. Jamsostek adalah suatu perlindungan bagi tenaga kerja dalam bentuk santunan berupa uang sebagai pengganti sebagian dari penghasilan yang hilang atau berkurang dan pelayanan sebagai akibat peristiwa atau keadaan yang dialami oleh tenaga kerja berupa kecelakaan kerja, sakit, hamil, bersalin, hari tua, dan meninggal dunia. ${ }^{20}$

Setiap tenaga kerja dan keluarganya berhak mendapatkan Jaminan Sosial Tenaga Kerja untuk kesejahteraan sesuai dengan Pasal 99 Undang-Undang Nomor 13 Tahun 2003 Tentang Ketenagakerjaan, yakni dengan mengikut sertakan pekerja dalam program Jaminan Sosial Tenaga Kerja (Jamsostek) yang meliputi (a) Jaminan kecelakaan kerja termasuk penyakit akibat kerja yang merupakan resiko yang harus dihadapi oleh tenaga kerja dalam melakukan pekerja. Jaminan kecelakaan ini, memberikan kompensasi dan rehabilitasi bagi tenaga kerja yang mengalami kecelakaan pada saat dimulai berangkat kerja sampai tiba kembali di rumah atau menderita penyakit akibat hubungan kerja. (b) Jaminan kematian, dimana tenaga kerja yang meninggal

19 Asri Wijayanti, 2009, Hukum Ketenagakerjaan Pasca Reformasi, Sinar Grafika, Jakarta, Hlm. 65

${ }^{20}$ Adrian Sutedi, 2009, Hukum Perburuhan, Sinar Grafika, Jakarta, Hlm. 173 
dunia akibat kecelakaan kerja, keluarganya berhak atas jaminan kematian (Pasal 12 ayat (1) UndangUndang Nomor 3 Tahun 1992), penegasan ini perlu, sebab apabila tenaga kerja meninggal dunia akibat kecelakaan kerja, maka keluarganya berhak atas santunan akibat kecelakaan kerja termasuk santunan kematian. (c) Jaminan hari tua yang dibayarkan sekaligus atau berkala, kepada pekerja karena (1) tenaga kerja telah mencapai usia 55 tahun, atau (2) cacat total tetap setelah ditetapkan oleh dokter. (d) Jaminan pemeliharaan kesehatan, dalam hal ini yang mendapatkan jaminan pemeliharaan kesehatan adalah pekerja, suami atau istri, dan anak yang sebanyak-banyaknya 3 (tiga) orang. Pemeliharaan kesehatan adalah hak pekerja dan yang merupakan salah satu program jamsostek yang membantu tenaga kerja dan keluarganya mengatasi masalah kesehatan. ${ }^{21}$

\section{b. Peraturan Pemerintah}

1. Peraturan Pemerintah No. 19 tahun 1973 tentang Pengaturan dan Pengawasan Keselamatan Kerja di Bidang Pertambangan

2. Peraturan Pemerintah No. 11 tahun 1979 tentang Keselamatan Kerja Pada Pemurnian dan Pengolahan Minyak dan Gas Bumi.

\section{c. Peraturan Menteri}

1. Peraturan Menteri Tenaga Kerja dan Transmigrasi R.I. No. Per.03/MEN/1978 tentang

21 Abdul Rachman Budiono, 1995, Hukum Perburuhan di Indonesia, RajaGrafindo Persada, Jakarta, Hlm. 240
Penunjukan dan Wewenang, Serta

Kewajiban Pegawai Pengawas

Keselamatan dan Kesehatan Kerja dan Ahli Keselamatan Kerja

2. Peraturan Menteri Tenaga Kerja dan Transmigrasi R.I. No. Per.01/MEN/1980 tentang Keselamatan dan Kesehatan Kerja pada Konstruksi Bangunan

3. Peraturan Menteri Tenaga Kerja R.I. No. Per.02/MEN/1992 tentang Tata Cara Penunjukan, Kewajiban dan Wewenang Ahli Keselamatan dan Kesehatan Kerja

4. Peraturan Menteri Tenaga Kerja R.I.. No. Per.05/MEN/1996 tentang Sistem Manajemen Keselamatan dan Kesehatan Kerja

5. Peraturan Menteri tenaga Kerja R.I. No. Per.01/MEN/1998 tentang Penyelenggaraan Pemeliharaan Kesehatan Bagi tenaga Kerja Dengan Manfaat Lebih dari Paket Jaminan Pemeliharaan Dasar Jaminan Sosial Tenaga Kerja.

\section{d. Keputusan Menteri Tentang K3}

1. Keputusan Menteri Tenaga Kerja No. Kep. 155/MEN/1984 Tentang Penyempurnaan Keputusan Menteri Tenaga Dan Transmigrasi Nomor Kep.125/MEN/82, Tentang Pembentukan, Susunan Dan Tata Kerja Dewan Keselamatan Dan Kesehatan Kerja Nasional, Dewan Keselamatan Dan Kesehatan Kerja Wilayah Dan Panitia Pembina Keselamatan Dan Kesehatan Kerja.

2. Keputusan Bersama Menteri Tenaga Kerja Dan Menteri Pekerjaan Umum 
Erni Darmayanti: Perlidungan Hukum Terhadap Pelaksanaan Keselamatan...

No.: Kep.174/MEN/1986. No.: 104/KPTS/1986 tentang Keselamatan Dan Kesehatan Kerja pada Tempat Kegiatan Konstruksi.

3. Keputusan Menteri Tenaga Kerja Dan Transmigrasi Republik Indonesia No.:Kep.235/MEN/2003 Tentang Jenis-Jenis Pekerjaan Yang Membahayakan Kesehatan, Keselamatan Atau Moral Anak.

\section{e. Instruksi Menteri}

Instruksi Menteri Tenaga Kerja No. Ins.11/M/BW/1997 tentang Pengawasan Khusus K3 Penanggulangan Kebakaran

Surat Edaran dan Keputusan Dirjen Pembinaan Hubungan Industrial Dan Pengawasan Ketenagakerjaan

1. Surat Keputusan Direktur Jenderal Pembinaan Hubungan Industrial Dan Pengawasan Ketenagakerjaan Departemen Tenaga Kerja R.I. No. : Kep. 84/BW/1998 Tentang Cara Pengisian Formulir Laporan dan Analisis Statistik Kecelakaan

2. Keputusan Direktur Jenderal Pembinaan Hubungan Industrial dan Pengawasan Ketenagakerjaan No. Kep.311/BW/2002 tentang Sertifikasi Kompetensi Keselamatan dan Kesehatan Kerja Teknisi Listrik.

\section{SIMPULAN}

Berdasarkan pembahasan tersebut, maka diambil kesimpulan bahwa keselamatan kerja termasuk dalam perlindungan teknis, yaitu perlindungan terhadap pekerja/ buruh agar selamat dari bahaya yang dapat ditimbulkan oleh alat kerja atau bahan kerja yang digunakan pekerja, begitupun dengan kesehatan kerja yaitu untuk melindungi atau menjaga pekerja dari kejadian atau keadaan kerja yang merugikan kesehatan dan kesusilaan pekerja dalam melakukan pekerjaannya. Dan perlindungan hukum Keselamatan dan Kesehatan Kerja dimuat dalam perundang-undangan yaitu Undang-Undang Nomor 1 Tahun 1970 Tentang Keselamatan Kerja, UndangUndang Nomor 13 Tahun 2003 Tentang Ketenagakerjaan yang memberikan, baik itu perlindungan hukum terhadap pekerja, pengupahan maupun kesejahteraan. Peraturan Pemerintah, Peraturan Menteri, Keputusan Menteri Mengenai Keselamatan dan Kesehatan Kerja (K3), Instruksi Menteri, dan Surat Edaran dan Keputusan Dirjen Pembinaan Hubungan Industrial dan Pengawasan Ketenagakerjaan.

\section{DAFTAR PUSTAKA}

Agusmidah, 2010, Dinamika Hukum Ketenagakerjaan Indonesia, USU Press, Medan.

Budiono, Abdul Rachmad, 1995, Hukum Perburuhan di Indonesia, PT. Raja Grafindo Persada, Jakarta.

Ibrahim, Johnny, 2007, Teori dan Metodologi Penelitian Hukum Normatif, Banyumedia, Jakarta.

Manulang, Sendjun H. 2001, PokokPokok Hukum Ketenagakerjaan Indonesia, PT. Asdi Mahasatya, Jakarta.

Ritonga, J.H., 1990, Pengetahuan Dasar Keselamatan Kerja Dan Pencegahan Kecelakaan, CV. Garut Narisi Corp, Jakarta. 
Rusli, Hardijan, 2004, Hukum Ketenagakerjaan, Ghalia Indonesia, Jakarta.

Silaban, Gerry dan Salomo Peranginangin, 2008, Hak Dan Atau Kewajiban Tenaga Kerja Dan Pengusahal Pengurus Yang Ditetapkan Dalam Peraturan Perundangan Keselamatan Dan Kesahatan Kerja, USU Press, Medan.

Suma'mur, 1987, Keselamatan Kerja dan Pencegahan Kecelakaan, CV. Haji Masagung, Jakarta.

Sutedi, Adrian, 2009, Hukum Perburuhan, Sinar Grafika,. Jakarta.

Wijayanti, Asri, Hukum Ketenagakerjaan Pasca Reformasi, Jakarta: Sinar Grafika, 2009.

http://seputarpengertian.blogspot.co.id/20 15/02/pengertian-umum-dan-tujuankeselamatan-kerja.html

http://www.safetyshoe.com/tag/pengertian -kesehatan-kerja/
Undang-Undang Republik Indonesia Nomor 13 Tahun 2003 Tentang Ketenagakerjaan.

Undang-Undang Republik Indonesia Nomor 1 Tahun 1970 Tentang Keselamatan Kerja.

Undang-Undang Nomor 3 Tahun 1992 Tentang Jaminan Sosial Tenaga Kerja.

Peraturan Menteri Tenaga Kerja Republik Indonesia Nomor Per-01/ Men/ 1998 Tentang Penyelenggaraan Pemeliharaan Kesehatan Bagi Tenaga Kerja Dengan Manfaat Lebih Baik Dari Paket Jaminan Pemeliharaan Kesehatan Dasar Jaminan Sosial Tenaga Kerja Menteri Tenaga Kerja Republik Indonesia. 